\title{
トルクュニットマニピュレータのーつの制御方策*
}

\author{
吉田 浩治 ${ }^{\dagger} \cdot$ 片山洋太朗 ${ }^{\dagger} \cdot$ 衣笠 哲也 ${ }^{\dagger} \cdot$ 福田 謙吾
}

\section{A Control Strategy for Torque-unit Manipulators*}

\author{
Koji Yoshida $^{\dagger}$, Yotaro Katayama ${ }^{\dagger}$, Tetsuya Kinugasa ${ }^{\dagger}$, \\ Kengo FUKUDA ${ }^{\ddagger}$ and Koichi OsUKA ${ }^{\S}$
}

\begin{abstract}
Torque-unit Manipulator (TUM) is a design concept of space manipulator. A device which is called "torque unit" is equipped on each link of a kinematic chain whose joints are all free. The "torque unit" can be made easily of a rotary actuator and a disc. TUM is a kind of nonholonomic system and the angular velocity of each disc at each time depends on the trajectories of the links. Controllability has been considered to control the position of each link to desired position and the angular velocity of each disc to desired constant value, by planning the trajectories of the links for 2-dimensional $N$ d.o.f. TUM. It consequently has been shown that it is impossible to control the angular velocity of each disc to desired constant value since TUM has a first integral. However the first integral allows us to control the angular velocities of the all discs to a constant value of zero. Then, a control strategy is considered and described based on the results of the consideration on the controllability of all state valuables of TUM in this paper.
\end{abstract}

\section{1. はじめに}

トルクユニットマニピュレータ (Torque-unit Manipulator: TUM) とはマニピュレータの設計概念 $[1,2]$ (Fig. 1) であり，通常のマニピュレータと同じくリンク が関節でつながれてできた系であるが, 次の特徵をもつ．

・ 各関節は 1 自由度の回転型非駆動関節である，

・各リンクにはトルクを発生する “トルクユニット”が 任意の位置に取り付けられる.

これは, 通常のマニピュレータにおいては関節が回転対 偶とトルクの発生という二つの機能を有することに対 して，TUM ではこれらを分解し関節に回転対偶のみの

* 原稿受付 2012 年 2 月 6 日

$\dagger$ 岡山理科大学 工学部 Faculty of Engineering, Okayama University of Science; 1-1 Ridai-cho, Kita-ku, Okayama city, Okayama 700-0005, JAPAN

‡株式会社 創発システム研究所 Sohatsu Systems Laboratory Inc.; 5-5-2, Minatojima-Minami, Chuo-ku, Kobe, Hyogo 650-0047, JAPAN

$\S$ 大阪大学大学院 工学研究科 Graduate School of Engineering, Osaka University; 2-1, Yamadaoka, Suita, Osaka 565-0871, JAPAN

Key Words: torque-unit manipulator, space manipulator, nonholonomic system, control strategy, planning motion trajectory.

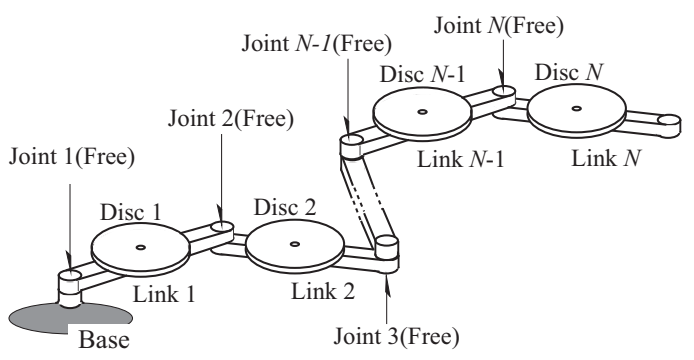

Fig. 1 TUM: A design concept of manipulator

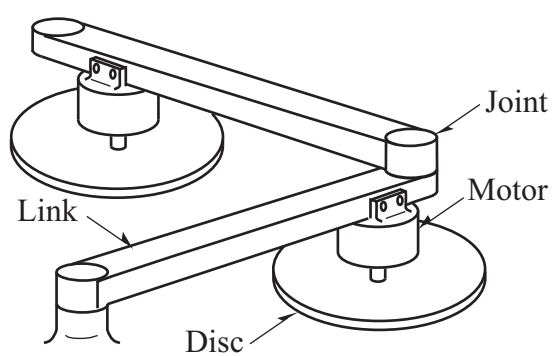

Fig. 2 Torque-unit

機能を, トルクユニットにトルク発生の機能を分け持た せたと考えることができる．トルクユニットはモータと 円盤で簡単に作ることができる . Fig. 2 に示すように， 
モータの軸に回転円盤を結合し，モータをリンクの任意 の位置に装着する．モータが回転円盤にトルクをおよぼ せばリンクには弚の反トルクがおよぼされる .このよう にしてこのトルクユニットは装着された产の位置でリン クにトルクをおよぼし光れを駆動する. 上述の特徵を有 するため，TUMには，

・保守の容易性，

・ 冗長アクチュエータ系の構成可能性

などの利点が生まれる.保守の容易性や冗長アクチュエー タ系 (一つのリンクに複数のトルクユニットを装着した 系) を構成できることは高信頼性を得ることができると 考えられる，高信頼性はマニピュレータか宇宙環境や危 険な場所での作業のために遠隔地にある場合には特に重 要であり，このような状況に対してマニピュレータの故 障の発見や部位の特定の方法および乥れへの対処の研 究がなされてきている [3-7]. TUM は朵長アクチュエー タ系を構成できることで, アクチュエータの故障に対し て有利である．TUMの動特性を表現する際，トルクユ ニット内の円盤は系を構成する一つのリンクと見なされ るが, 乥れらの変位角度は意味を持たず, 運動方程式に は各リンクの角度, 角速度および角加速度, 乥して各円 盤の角速度と角加速度のみか現れる. 状態変数は各リン クの角度，角速度，および各円盤の角速度となる. 光し て TUM は 2 階の非ホロノミックな拘束を持つ系となる ことが知られている $[8]$.

同じく 2 階の非ホロノミックな拘束を持つマニピュ レータに非駆動関節を有する劣駆動マニピュレータがあ る.このような系では, システムの軽量化や単純化が可 能である．さらに，コストやエネルギー消費の低減と いった利点を有する．また，なんらかの対象にハンマー を打ち付けるといった衝撃を伴う作業への応用や通常の マニピュレータにおいてアクチュエータガ故障した際の 対処の方策としての応用も考えられる [23] . 劣駆動マ二 ピュレータは運動計画と制御の観点から，特に理論的に 非常に興味深い対象であり，多くの研究がなされてきて いる [9-27]. De Lucaら [16] は劣駆動マニピュレータに おける問題点をあらためて明確に整理して述べ，系の解 析，運動計画および制御について光れまでになされた研 究の非常に良いまとめを与えている.さらに, 2009 年に Roy and Asada[27] は航空機の翼を構成する wing box とよばれる部分の組立て作業に用いることを目的として 劣駆動マニピュレータの研究を進めている.乥こでは劣 駆動マニピュレータの持つ軽量性やコンパクト性の利点 が活かされている.理論的な興味だけではなく実際のア プリケーションも注目され始めている .

TUM がこれらの系と異なる点は, TUM の各リンク にはトルクユニットが装着されているために , トルクユ ニット内の円盤の運動を無視すれば，リンクに関しては 通常のマニピュレータと同樣に扱うことができることで ある、ただし，リンクを従来の制御則て位置制御すると，
一般にトルクユニット内の円盤に残留角速度が生じてし まう.すなわち, 各リンクが目標位置に到達した後も円 盤は一定の角速度で運動を続けてしまう.(円盤が一定の 角速度で回転している時にはリンクにはトルクをおよぼ さない.)

これを契機として, 2 次元平面内のみを運動できる TUM を対象としてTUM の運動軌道を計画することに よる状態変数の可制御性についての議論がなされた $[28]$. ある時点のトルクユニット内の円盤の角速度は, 弚の時 点までのTUMのリンクの運動履歴に依存する .この性 質を用いて，TUM が任意の初期姿勢で静止し，各円盤 が任意の一定値で回転している時, リンクの運動軌道を 計画し, 弚れに沿って運動を行わせることで任意の姿勢 に制御し，かつ，各円盤の角速度を任意の一定値にする ことの可能性について検討がなされた . 弚の結果, TUM には第一積分が存在するため, TUM を任意の姿勢に制 御できても，弚の時同時に円盤の角速度をすべて任意 の值にすることは不可能であり, 可制御ではないことが わかった .ただし，この第一積分は「円盤の全角運動量 は保存される」ことを意味している .このことにより， TUM が任意の初期姿勢で静止し, 各円盤の角速度が 0 の初期状態から TUM が任意の目標姿勢で静止し，各円 盤の角速度が 0 の目標状態へは制御できる.TUM を運 用する際には多くの場合これができれば十分であると思 われる .

本論文では, TUMのリンクの軌道計画による可制御 性の考察 [28] に基づいて, TUM が任意の初期姿勢で静 止し, 各円盤の角速度が 0 の初期状態から任意の目標姿 勢で静止し, 各円盤の角速度が 0 の目標状態への制御方 策を考察する.TUMのリンクの軌道計画による可制御 性の考察においては円盤の角速度を任意の值にする軌道 が存在することを構成することで示したが, 軌道計画に はTUM を構成するリンクと円盤の物理パラメータ（質 量や慣性モーメントなど）について真值が必要であった . これは軌道計画を実施する際の非常な困難となる.しか し，本論文での考察の結果では光れらの物理パラメータ 值が不確かさを含む推定値あるいは概算值の場合でも各 円盤の角速度を 0 に漸近させることができる．

本論文では, 2. で平面内を運動する TUM の動特性モ デルについて短く述べる．3.では物理パラメータ值に不 確かさを含む場合でも各円盤の角速度を 0 に漸近させる 問題を考察し, TUMの一つの制御方策を述べる.4.で はシミュレーションによって 3.の結果を確認する .5.で まとめと今後の課題について述べる .

\section{2. $N$ 自由度 TUM}

Fig. 3 は本研究で対象とする TUM である. 图に示 すように 2 次元平面内を運動する $N$ 自由度の TUM で ある. 重力の影響はない状況を考える.すべての関節 軸は平行でトルクユニットを構成する円盤の回転軸も 


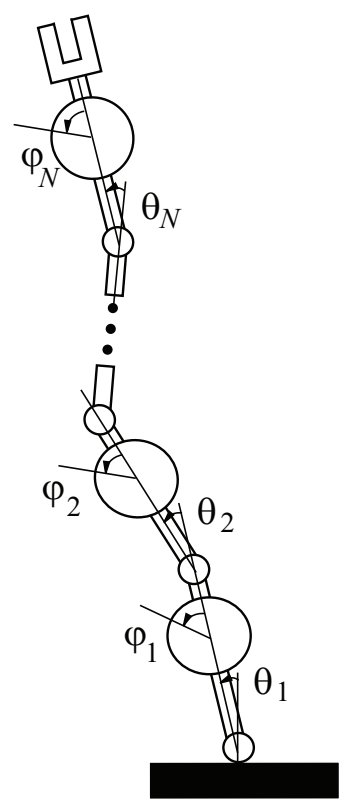

Fig. 3 2-dimensional TUM

すべて平行で関節軸にも平行である.リンク $i$ に座標 系 $\left(o_{i} ; \boldsymbol{x}_{i}, \boldsymbol{y}_{i}, \boldsymbol{z}_{i}\right)$ を設定し, リンクの長手方向に $\boldsymbol{x}_{i}$ を とる. 円盤 $i$ に座標系 $\left(o_{d i} ; \boldsymbol{x}_{d i}, \boldsymbol{y}_{d i}, \boldsymbol{z}_{d i}\right)$ を適切に設定す る . 円盤の座標軸の一つを円盤の回転軸に一致させ ，座 標系原点を円盤の質量中心に設定する．このとき，リ ンク $i$ の関節角度を $\theta_{i}$ で表し，関節角度べクトルを $\boldsymbol{\theta}=\left[\begin{array}{llll}\theta_{1} & \theta_{2} & \cdots & \theta_{N}\end{array}\right]^{\mathrm{T}}$ と定義する.また，円盤の回転 角度を $\varphi_{i}$ で表し， $\varphi=\left[\begin{array}{llll}\varphi_{1} & \varphi_{2} & \cdots & \varphi_{N}\end{array}\right]^{\mathrm{T}}$ を定義する。

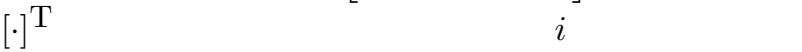
を $m_{i}$, 質量中心回りの慣性モーメントを $I_{i}$ で表し， $o_{i}$

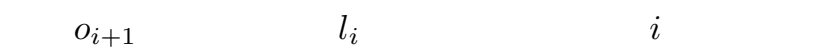
質量を $m_{d i}$ で, 回転軸回りの慣性モーメントを $I_{d i}$ で表 す .ここで, リンク $i$ の質量中心と $o_{d i}$ は $o_{i}$ と $o_{i+1}$ とを 結ふ線分上にあるとする .このとき $r_{i}$ を $o_{i}$ からリンク $i$ の質量中心までの距離とし,$o_{i}$ から $o_{d i}$ までの距離を $l_{d i}$ で表す．また，これらを用いてつぎの量を定義する．

$$
\begin{aligned}
& M_{i}=\sum_{j=i}^{N}\left(m_{j}+m_{d j}\right) \\
& R_{i}=m_{i} r_{i}+M_{i+1} l_{i}+m_{d i} l_{d i}
\end{aligned}
$$

運動方程式は次のように導出されている $[28]$.

$$
\begin{aligned}
\boldsymbol{H}_{11}(\boldsymbol{\theta}) \ddot{\boldsymbol{\theta}} & +\boldsymbol{H}_{12}(\boldsymbol{\theta}) \ddot{\boldsymbol{\varphi}}+\dot{\boldsymbol{H}}_{11}(\boldsymbol{\theta}) \dot{\boldsymbol{\theta}} \\
& -\frac{\partial}{\partial \boldsymbol{\theta}}\left(\frac{1}{2} \dot{\boldsymbol{\theta}}^{\mathrm{T}} \boldsymbol{H}_{11}(\boldsymbol{\theta}) \dot{\boldsymbol{\theta}}\right)=\mathbf{0} \\
\boldsymbol{H}_{12}^{\mathrm{T}}(\boldsymbol{\theta}) \ddot{\boldsymbol{\theta}} & +\boldsymbol{H}_{22} \ddot{\boldsymbol{\varphi}}=\boldsymbol{\tau}_{d i s c}
\end{aligned}
$$

ここで, $\boldsymbol{H}_{11}(\boldsymbol{\theta})$ は円盤を固着したときのリンク系の慣 性行列, $\boldsymbol{H}_{12}$ は円盤の回転軸回りの慣性モーメントを要
素に持つ上三角行列で

$$
\boldsymbol{H}_{12}=\left[\begin{array}{cccc}
I_{d 1} & I_{d 2} & \cdots & I_{d N} \\
& I_{d 2} & \cdots & I_{d N} \\
& & \ddots & \vdots \\
& & & I_{d N}
\end{array}\right]
$$

$\boldsymbol{H}_{22}$ は円盤の回転軸回りの慣性モーメントを要素に持つ 対角行列で

$$
\boldsymbol{H}_{22}=\operatorname{diag}\left[I_{d 1}, I_{d 2}, \cdots, I_{d N}\right]
$$

$\boldsymbol{\tau}_{\text {disc }}=\left[\begin{array}{llll}\tau_{\text {disc1 } 1} & \tau_{\text {disc } 2} \cdots & \tau_{\text {discN }}\end{array}\right]^{\mathrm{T}}$ は円盤への入カトル クベクトルである.(詳細は参考文献 $[28]$ を参照のこと .) TUM はリンクの角度のみに注目し，円盤の運動を考慮 しなければ, 通常のマニピュレータと同じ運動方程式と なり通常のマニピュレータと同樣に扱うことができる $[8]$.

\section{TUM の制御方策}

まず，本論文で考察する問題はつぎである .

問題 TUMの初期状態 :

$$
\boldsymbol{\theta}=\boldsymbol{\theta}_{s} \dot{\boldsymbol{\theta}}=\mathbf{0} \dot{\varphi}=\mathbf{0}
$$

$\left(\theta_{s}\right.$ は任意の姿勢 $)$ から終端状態 :

$$
\boldsymbol{\theta}=\boldsymbol{\theta}_{d} \dot{\boldsymbol{\theta}}=\mathbf{0} \dot{\varphi}=\mathbf{0}
$$

$\left(\theta_{d}\right.$ (は目標姿勢 $)$ 一至らせる制御方策を構成せよ .

このような，円盤か清争止した初期状態から同じく静止 した目標状態への制御の場合には TUMの可制御性を議 論する以前に大須賀ら $[8]$ か制御方策を提案している.こ の方策はリンクを絶対角で見て一つずつ運動させる軌道 を計画し，弚の計画されたリンクの軌道にフィードバッ ク制御で追従させることで, リンクが目標状態に至った 時点で各円盤の角速度を任意に小さくできることを示し ている . ある時点での円盤の角速度はTUMのリンクの 運動軌道だけに依存しているので, この方策の本質は目 的を実現するリンクの運動軌道を見つけることにある． しかし , リンクを一つずつ運動させる必要があるので， PTP(point-to-point) 制御となり障害物の有無など作業 空間の都合によりリンクの軌道に制約がある場合は軌 道計画に非常な労力を要することになる . 本論文では， そのような欠点を改善するべく，制御方策を新たに考察 する .

まず，つぎの問題 1 に対して解が与えられている .

問題 $1 \mathrm{TUM}$ は初期状態でリンクが任意の位置て静止 し円盤は任意の一定角速度を持つとする.このとき, 各 リンクが運動し $T$ 秒後のリンクの位置が初期状態と同じ 状態で静止し，产の時点で円盤の角速度を任意の一定值 にするようなリンクの運動軌道はあるか．

これに対してつぎの命題が与えられている $[28]$. 
【命題 1】 TUMには第一積分が存在し， $N$ 個の円盤 の角速度の間にはつぎの拘束条件がある。

$$
\sum_{i=1}^{N} I_{d i} \dot{\varphi}_{i}(T)=\sum_{i=1}^{N} I_{d i} \dot{\varphi}_{i}(0) \quad \text { :const }
$$

このため， $N$ 個すべての円盤の角速度を任意の一定值に することは構造的に不可能であるが， $N-1$ 個を任意の 一定値にするようなリンクの運動軌道はすくなくとも一 つは存在する .

この命題 1 は非ホロノミック系が持つ特徵的な holonomy あるいは geometric phase[29] を利用した方法であ り，TUM という系を詳細に調べることで得られた結果 である .この holonomy の応用は広い分野で行われてき たが，ロボティクスの分野では [30-34] などがあり，光 れ光れの系に巧みに用いられて有用な結果を生み出して いる.この命題 1 を用いれば，問題を二つに分けて考え ることができる .

- STEP 1 TUMのリンクについて任意の姿勢で静 止した状態から目標姿勢で静止した状態への制御

-STEP 2 リンクが目標姿勢に至った後, 各円盤の 角速度を 0 にする制御

STEP 1では円盤の運動を無視して TUM 取り扱つ てよいことになる .このとき，TUM は通常のマニピュ レータと同樣になり，必要であれば最適時間制御や障害 物回避の方策など今までの樣々な知見 (たとえば[35-37]) を用いることができる．つぎに命題 1 により運動軌道を 計画することで $N-1$ 個の円盤の角速度を 0 にでき，リ ンクは目標位置に戻すことができる．このとき，初期状 態で各円盤か清争止している場合は，第一積分である (9) 式が 0 であるので, 残りの1個の円盤の角速度は必然的 に0になり，すべての円盤の角速度を 0 にすることがで きる.STEP 2 では命題 1 に沿って運動軌道を計画し計 画された軌道に十分に精度良く追従させるための制御則 を与えることで各円盤の角速度を 0 にすることができる．

このように二つに分けると, STEP 2 はSTEP 1 に 必ずしも引き続いて実行することもないことがわかる． たとえば，STEP 1 によってマニピュレータに pickand-place 作業を複数回おこなわせた後, 円盤に蓄積し た残留角速度を零にするためのSTEP 2 を実施するこ とも考えられる .

ところが, 命題 1 に沿って軌道を計画しようとすると TUM の物理パラメータの真値が必要になる $[28]$. 真值 を得ることは不可能であり，さらに, pick-and-place 作 業などでハンドに何か搬送物を持つ場合は, 弚れの物理 パラメータ值も必要になる .これは軌道計画を実施する うえで非常な困難となる．乥こで本論文の主結果である 次の命題を与える.
3.1 円盤の残留角速度を 0 に漸近させるための 運動軌道

【命題 2】時刻 $t_{p-1}$ において TUM の各リンクは光 れぞれの位置で静止していて，各円盤は一定の角速度で 回転しているとする .このとき，円盤 $m(m=2,3, \cdots, N)$ に注目し次式のように軌道を計画する .

- $m=N$ の場合

$$
\begin{aligned}
& \dot{\theta}_{N-1}(t)=B \sin \omega\left(t-t_{p-1}\right), \quad \omega=\frac{2 \pi}{t_{p}-t_{p-1}}, \\
& \dot{\theta}_{i}(t)=0 \\
& \quad(i=1,2, \cdots, N-2, N)
\end{aligned}
$$

- $3 \leq m \leq N-1$ の場合

$$
\begin{aligned}
& \dot{\theta}_{m-1}(t)=B \sin \omega\left(t-t_{p-1}\right), \quad \omega=\frac{2 \pi}{t_{p}-t_{p-1}}, \\
& \dot{\theta}_{m+1}(t)=-\dot{\theta}_{m-1}(t), \\
& \dot{\theta}_{i}(t)=0 \\
& \quad(i=1,2, \cdots, m-2, m, m+2, \cdots, N-1, N)
\end{aligned}
$$

- $m=2$ の場合

$$
\begin{aligned}
\dot{\theta}_{1}(t) & =B \sin \omega\left(t-t_{p-1}\right), \quad \omega=\frac{2 \pi}{t_{p}-t_{p-1}}, \\
\dot{\theta}_{3}(t) & =-\dot{\theta}_{1}(t), \\
\dot{\theta}_{i}(t) & =0 \\
(i & =2,4, \cdots, N-1, N)
\end{aligned}
$$

ここで,$B=\sqrt{a} \sqrt{\left|\dot{\varphi}_{d m}-\dot{\varphi}_{m}\left(t_{p-1}\right)\right|}$ とする.$a$ は定 数であり, $\dot{\varphi}_{d m}$ は円盤 $m$ の目標角速度である . また， $\dot{\varphi}_{m}\left(t_{p-1}\right)$ は時刻 $t_{p-1}$ における円盤 $m$ の角速度である. $\mathrm{TUM}$ は時刻 $t_{p-1}$ で動き始め時刻 $t_{p}$ で各リンクは元の 位置に戻り静止する.

このとき，TUM がこの軌道に沿って運動を繰り返し たとき，ただし $B$ は運動ごとで更新するが， 円盤 $m$ の 角速度を，運動か終了するごとに任意の目標值に漸近さ せることができる $\theta_{m}$ と $a$ の範囲が存在する.$\left(\theta_{m}\right.$ はリ ンク $m$ の位置であり，運動中は一定值として計画されて (る.)

(証明) リンクに関する運動方程式 (3) をリンクが運 動した時間で積分する .このとき, $\dot{\boldsymbol{\theta}}\left(t_{p-1}\right)=\dot{\boldsymbol{\theta}}\left(t_{p}\right)=\mathbf{0}$ を考慮すると，

$$
\begin{aligned}
& \int_{t_{p-1}}^{t_{p}} \sum_{j=i}^{N} I_{d j} \ddot{\varphi}_{j} d t \\
= & \int_{t_{p-1}}^{t_{p}} \frac{\partial}{\partial \theta_{i}}\left(\frac{1}{2} \dot{\boldsymbol{\theta}}^{\mathrm{T}} \boldsymbol{H}_{11}(\boldsymbol{\theta}) \dot{\boldsymbol{\theta}}\right) d t \quad(i=1,2, \cdots, N)
\end{aligned}
$$

を得る.ここで, 円盤 $m$ の角速度を目標値に漸近させた いので, (13) 式で $i=m$ の式に注目し，

$$
\frac{\partial}{\partial \theta_{m}}\left(\frac{1}{2} \dot{\boldsymbol{\theta}}^{\mathrm{T}} \boldsymbol{H}_{11}(\boldsymbol{\theta}) \dot{\boldsymbol{\theta}}\right)
$$


を調べる

$$
\begin{aligned}
& \frac{\partial}{\partial \theta_{m}}\left(\frac{1}{2} \dot{\boldsymbol{\theta}}^{\mathrm{T}} \boldsymbol{H}_{11}(\boldsymbol{\theta}) \dot{\boldsymbol{\theta}}\right) \\
= & -\sum_{i=1}^{m-1} l_{i}\left(\sum_{k=1}^{i} \dot{\theta}_{k}\right) \sum_{j=m}^{N} R_{j}\left(\sum_{q=1}^{j} \dot{\theta}_{q}\right) \sin \left(\sum_{p=i+1}^{j} \theta_{p}\right)
\end{aligned}
$$

であることが簡単な計算によってわかる .このとき上の ように軌道を計画すると, $\frac{\partial}{\partial \theta_{m}}\left(\frac{1}{2} \dot{\boldsymbol{\theta}}^{\mathrm{T}} \boldsymbol{H}_{11}(\boldsymbol{\theta}) \dot{\boldsymbol{\theta}}\right)$ は

$$
-l_{m-1} R_{m} \dot{\theta}_{m-1}^{2} \sin \theta_{m}
$$

となる (他の項はすべて 0 となる ) さらに,$m \leq N-1$ ならば

$$
\begin{aligned}
\frac{\partial}{\partial \theta_{j}}\left(\frac{1}{2} \dot{\boldsymbol{\theta}}^{\mathrm{T}} \boldsymbol{H}_{11}(\boldsymbol{\theta}) \dot{\boldsymbol{\theta}}\right) & =0 \\
(j & =m+1, m+2, \cdots, N)
\end{aligned}
$$

となる.なぜならば , $\frac{\partial}{\partial \theta_{j}}\left(\frac{1}{2} \dot{\boldsymbol{\theta}}^{\mathrm{T}} \boldsymbol{H}_{11}(\boldsymbol{\theta}) \dot{\boldsymbol{\theta}}\right)(j=m+1, m+$ $2, \cdots, N)$ の各項は $\sum_{p=1}^{j} \dot{\theta}_{p}(=0)$ を積の形で含むからであ る.よって , (13) 式の $i=m$ の式は次式となる .

$$
\begin{aligned}
& \int_{t_{p-1}}^{t_{p}} I_{d m} \ddot{\varphi}_{m} d t+\int_{t_{p-1}}^{t_{p}} \sum_{j=m+1}^{N} I_{d j} \ddot{\varphi}_{j} d t \\
= & -\int_{t_{p-1}}^{t_{p}} l_{m-1} R_{m} \dot{\theta}_{m-1}^{2} \sin \theta_{m} d t \\
\Rightarrow & \int_{t_{p-1}}^{t_{p}} I_{d m} \ddot{\varphi}_{m} d t \\
= & -\int_{t_{p-1}}^{t_{p}} l_{m-1} R_{m} \dot{\theta}_{m-1}^{2} \sin \theta_{m} d t
\end{aligned}
$$

$\theta_{m}$ が定数であることを考慮し積分を実行すると，

$$
\begin{aligned}
& \dot{\varphi}_{m}\left(t_{p}\right)-\dot{\varphi}_{m}\left(t_{p-1}\right) \\
= & \frac{-\sin \theta_{m} l_{m-1} R_{m} B^{2}\left(t_{p}-t_{p-1}\right)}{2 I_{d m}}
\end{aligned}
$$

となる $. B=\sqrt{a} \sqrt{\left|\dot{\varphi}_{d m}-\dot{\varphi}_{m}\left(t_{p-1}\right)\right|}$ を代入すると，

$$
\begin{aligned}
\dot{\varphi}_{m}\left(t_{p}\right)= & \frac{-\sin \theta_{m} l_{m-1} R_{m}\left(t_{p}-t_{p-1}\right)}{2 I_{d m}} a \\
& \times\left|\dot{\varphi}_{d m}-\dot{\varphi}_{m}\left(t_{p-1}\right)\right|+\dot{\varphi}_{m}\left(t_{p-1}\right)
\end{aligned}
$$

となる. 運動後での円盤角速度の目標値 $\dot{\varphi}_{d m}$ との差を評 価する

$$
\begin{aligned}
& \left|\dot{\varphi}_{d m}-\dot{\varphi}_{m}\left(t_{p}\right)\right| \\
= & \mid \dot{\varphi}_{d m}-\dot{\varphi}_{m}\left(t_{p-1}\right) \\
& +a b \sin \theta_{m}\left|\dot{\varphi}_{d m}-\dot{\varphi}_{m}\left(t_{p-1}\right)\right| \mid
\end{aligned}
$$

ここで，

$$
b=\frac{l_{m-1} R_{m}\left(t_{p}-t_{p-1}\right)}{2 I_{d m}}
$$

とした・さて，

$$
\left|\dot{\varphi}_{d m}-\dot{\varphi}_{m}\left(t_{p}\right)\right|<\left|\dot{\varphi}_{d m}-\dot{\varphi}_{m}\left(t_{p-1}\right)\right|
$$

となれば計画した軌道に沿った運動ごとに円盤 $m$ の角速 度 $\dot{\varphi}_{m}(t)$ は目標値に近づく．弚のための条件を調べる。

$$
\bullet \dot{\varphi}_{d m}-\dot{\varphi}_{m}\left(t_{p-1}\right)>0 \text { のとき }
$$$$
\left|1+a b \sin \theta_{m}\right|<1
$$

ならば(23)式が成立する .ここで, $\sin \theta_{m} \geq 0$ ならば， $a$ ， $b$ ともに正なので $(24)$ 式は成立しない . また, $\sin \theta_{m}<0$ ならば

$$
0<a<\frac{-2}{b \sin \theta_{m}}
$$

のとき $(24)$ 式が成立する .

$$
\begin{aligned}
& \bullet \dot{\varphi}_{d m}-\dot{\varphi}_{m}\left(t_{p-1}\right)<0 \text { のとき } \\
& \left|1-a b \sin \theta_{m}\right|<1
\end{aligned}
$$

ならば(23)式が成立する.ここで, $\sin \theta_{m} \leq 0$ ならば， $a$ ， $b$ ともに正なので $(26)$ 式は成立しない . また, $\sin \theta_{m}>0$ ならば

$$
0<a<\frac{2}{b \sin \theta_{m}}
$$

のとき (26) 式が成立する .

以上で円盤 $m(m=2,3, \cdots, N)$ の角速度を任意の目 標值に近づけることができる， $\theta_{m}$ と $a$ の範囲を示すこ とができた .

このようにリンクが運動したとき, 円盤 $m(m=$ $2,3, \cdots, N)$ の角速度を目標值に近づけることができる． さらに， $m \neq N$ である円盤 $m$ については角速度を目標 值に近づけることができる一方で, 光の円盤より先端側

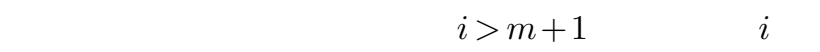
角速度は繰り返される運動前後て変化はない．これにつ いては, 軌道計画における $B$ の值には関係なく $(17)$ 式 が成立することで得られる .

この命題 2 を用いると，(10)-(12) 式でリンクの運動 軌道を計画し, 必要な回数だけ繰り返して運動させれば 円盤 $m$ の角速度は目標値を 0 とすることで 0 に漸近させ ることができる. 運動軌道における振幅 $B$ は円盤の現時 点における角速度 $\dot{\varphi}_{m}\left(t_{p-1}\right)$ と定数 $a$ によって決定すれ ばよく，aの值は次式で示される範囲にあればよいこと になる .

$$
0<a<\left|\frac{2}{b \sin \theta_{m}}\right|
$$

上限の值は物理パラメータ值と制御時間および $\theta_{m}$ で決 定される．したがって，あらかじめ得られた物理パラ メータ值の推定值や概算值を用いれば $a$ を設定できる． そして，これを円盤 $N$ の角速度に対して実施を開始し， 
順次 , 円盤 2 の角速度に対してまで実施すればこれらの 円盤の角速度を 0 に近づけることができる .このとき， TUM の第一積分である $(9)$ 式を考慮すると，初期状態 で円盤の角速度はすべて0であったので

$$
\sum_{i=1}^{N} I_{d i} \dot{\varphi}_{i}(T)=\sum_{i=1}^{N} I_{d i} \dot{\varphi}_{i}(0)=0
$$

により円盤 1 の角速度も十分に 0 に近い値となっている． ただし , 命題 2 で示したように, 円盤 $m$ の角速度と目標 值との誤差の正負によってリンク $m$ の角度 $\theta_{m}$ を変更す る必要が生じる場合がある．これについては文献 [28]に おける補題を用いることで解決できる．すなわち，必要 に応じてリンク $m$ の角度を変更する運動をおこなって も，運動前後ですべての円盤の角速度に変化が生じない ようにすることは可能である .

3.2 STEP 2 における軌道追従のための制御則 STEP 2 において計画された運動軌道にリンクを追 従させるための制御則に PD 型二重構造ロバストモデル 追従制御 [38] を用いる.これによりモデリング誤差に対 してロバストであり，固定ゲイン型の制御系が構成でき る.制御則を次のように与える . (3) 式および(4)式より 䒜を消去すると，

$$
\begin{aligned}
\boldsymbol{\tau}_{d i s c}= & -\left(\boldsymbol{H}_{12} \boldsymbol{H}_{22}^{-1}\right)^{-1} \\
& {\left[\left(\boldsymbol{H}_{11}(\boldsymbol{\theta})-\boldsymbol{H}_{12} \boldsymbol{H}_{22}^{-1} \boldsymbol{H}_{12}^{\mathrm{T}}\right) \ddot{\boldsymbol{\theta}}\right.} \\
& \left.+\dot{\boldsymbol{H}}_{11}(\boldsymbol{\theta}) \dot{\boldsymbol{\theta}}-\frac{\partial}{\partial \boldsymbol{\theta}}\left(\frac{1}{2} \dot{\boldsymbol{\theta}}^{\mathrm{T}} \boldsymbol{H}_{11}(\boldsymbol{\theta}) \dot{\boldsymbol{\theta}}\right)\right]
\end{aligned}
$$

が得られるので，

$$
\begin{aligned}
\boldsymbol{J}(\boldsymbol{\theta})= & -\left(\boldsymbol{H}_{12} \boldsymbol{H}_{22}^{-1}\right)^{-1} \\
& {\left[\left(\boldsymbol{H}_{11}(\boldsymbol{\theta})-\boldsymbol{H}_{12} \boldsymbol{H}_{22}^{-1} \boldsymbol{H}_{12}^{\mathrm{T}}\right)\right], } \\
\boldsymbol{f}(\boldsymbol{\theta}, \dot{\boldsymbol{\theta}})= & -\left(\boldsymbol{H}_{12} \boldsymbol{H}_{22}^{-1}\right)^{-1} \\
& {\left[\dot{\boldsymbol{H}}_{11}(\boldsymbol{\theta}) \dot{\boldsymbol{\theta}}-\frac{\partial}{\partial \boldsymbol{\theta}}\left(\frac{1}{2} \dot{\boldsymbol{\theta}}^{\mathrm{T}} \boldsymbol{H}_{11}(\boldsymbol{\theta}) \dot{\boldsymbol{\theta}}\right)\right] }
\end{aligned}
$$

として , 入力 $\boldsymbol{u}$ を次のように決定する .

$$
\begin{aligned}
& \boldsymbol{u}=\hat{\boldsymbol{J}}(\boldsymbol{\theta})\left(\boldsymbol{u}_{M}+\boldsymbol{\tau}\right)+\hat{\boldsymbol{f}}(\boldsymbol{\theta}, \dot{\boldsymbol{\theta}}), \\
& \boldsymbol{u}_{M}=\ddot{\boldsymbol{\theta}}_{d}-b_{2}\left(\dot{\boldsymbol{\theta}}_{M}-\dot{\boldsymbol{\theta}}_{d}\right)-b_{1}\left(\boldsymbol{\theta}_{M}-\boldsymbol{\theta}_{d}\right), \\
& \boldsymbol{\tau}=-k h_{2}\left(\dot{\boldsymbol{\theta}}-\dot{\boldsymbol{\theta}}_{M}\right)-k h_{1}\left(\boldsymbol{\theta}-\boldsymbol{\theta}_{M}\right) \\
& \text { こで }, \boldsymbol{\theta}_{M} \text { と } \dot{\boldsymbol{\theta}}_{M} \text { は } \\
& \ddot{\boldsymbol{\theta}}_{M}=\boldsymbol{u}_{M}
\end{aligned}
$$

で構成された線形中間モデルから得られる出力であり， $\ddot{\boldsymbol{\theta}}_{d}(t), \dot{\boldsymbol{\theta}}_{d}(t), \boldsymbol{\theta}_{d}(t)$ は目標軌道である.また， $b_{1}, b_{2}$ ， $k h_{1}, k h_{2}$ はゲインである . $\hat{\boldsymbol{J}}(\boldsymbol{\theta})$ と $\hat{\boldsymbol{f}}(\boldsymbol{\theta}, \dot{\boldsymbol{\theta}})$ は物理パラ メータの推定值や概算值および $\boldsymbol{\theta}, \dot{\theta}$ で得られる慣性行 列とコリオリ・中心力項である . このとき , 目標軌道の 初期状態を TUM の運動開始前の状態に一致させておけ ば，任意の時刻で必要な精度で目標軌道に追従させるこ とができる .

\section{4. 制御方策のシミュレーション}

3.で考察した制御方策のシミュレーションをおこなう . 本論文の主結果である，STEP 2 において TUM が計 画された運動軌道に沿って繰り返し運動をおこなうこと によって円盤の残留角速度を 0 に漸近させることができ ることを確認する . 2 次元平面内の 3 リンクの TUM を 用いてシミュレーションをおこなう．

\subsection{3 自由度 TUM}

TUM の各リンクはアルミ棒で, トルクユニットの円 盤は鉄製, モ一タは小型のDC サーボモータで構成され ているものとした . 諸元を Table 1 に示す . 三つのリン クの諸元は同じにした .これらは, 文献 [28] における シミュレーションで用いた諸元と同じであり，現実の物 に即した量である．また， $b_{1}=10 ， b_{2}=30 ， k h_{1}=330$ ， $k h_{2}=330$ とした . $\hat{\boldsymbol{J}}(\boldsymbol{\theta})$ と $\hat{\boldsymbol{f}}(\boldsymbol{\theta}, \dot{\boldsymbol{\theta}})$ は TUM の基底パラ

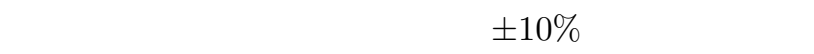
を用いて計算した .これは, TUMの運動データでパラ メータ同定をおこない, 弚れによって得られたパラメー タ值を用いることを考えていることによる．aについて は誤差を含む基底パラメータ値を用いて (28) 式の上限 値を計算し乥れに 0.98 を乗じた值を用いた . シミュレー ションでは, STEP 1 においても目標軌道を計画して 同じ制御側を用いることにする .

Table 1 Physical parameter value

\begin{tabular}{|c|c|}
\hline Parameter & Value \\
\hline$l_{i}$ & $0.3[\mathrm{~m}]$ \\
\hline$m_{i}$ & $0.806[\mathrm{~kg}]$ \\
\hline$r_{i}$ & $0.15[\mathrm{~m}]$ \\
\hline$I_{i}$ & $0.00380\left[\mathrm{kgm}{ }^{2}\right]$ \\
\hline$l_{d i}$ & $0.15[\mathrm{~m}]$ \\
\hline$m_{d i}$ & $0.176[\mathrm{~kg}]$ \\
\hline$I_{d i}$ & $0.00234\left[\mathrm{kgm}^{2}\right]$ \\
\hline
\end{tabular}

\section{2 シミュレーション}

STEP 1 として, すべてのリンクと円盤の角速度が0 (静止状態) の初期状態からリンクをある目標角度に制 御したのち，STEP 2 として，炎のとき生じた円盤の残 留角速度を 0 に近づける.まず，

- 初期状態:

$$
\boldsymbol{\theta}(0)=\left(\begin{array}{c}
\pi / 3 \\
\pi / 4 \\
-\pi / 6
\end{array}\right)[\mathrm{rad}], \dot{\boldsymbol{\theta}}(0)=\dot{\boldsymbol{\varphi}}(0)=\mathbf{0}[\mathrm{rad} / \mathrm{s}]
$$

- 目標状態:

$$
\boldsymbol{\theta}(T)=\left(\begin{array}{c}
3 \pi / 4 \\
-\pi / 6 \\
-\pi / 2
\end{array}\right)[\mathrm{rad}], \dot{\boldsymbol{\theta}}(T)=\dot{\boldsymbol{\varphi}}(T)=\mathbf{0}[\mathrm{rad} / \mathrm{s}](35)
$$


とする

- STEP $1\left(0 \leq t \leq 5\left(=t_{1}\right)\right)$ : 各リンクを目標角度に 制御する。

目標角度までの各リンクの目標軌道を次式のように 時間に関する 3 次の多項式で作成する.

$$
\theta_{d i}=a_{i, 0}+a_{i, 1} t+a_{i, 2} t^{2}+a_{i, 3} t^{3}
$$

ここで, $a_{i, j}(i=1,2,3, j=0,1,2,3)$ は初期状態に おける角度と目標角度および運動に必要とする時間 によって一意に決定できる. $\dot{\theta}_{d i}, \ddot{\theta}_{d i}(i=1,2,3)$ は (36) 式を時間微分することで得られる .

各リンクが目標角度に到達したとき, $\dot{\varphi}_{1}\left(t_{1}\right)=$ $4.1047[\mathrm{rad} / \mathrm{s}], \dot{\varphi}_{2}\left(t_{1}\right)=-0.0002[\mathrm{rad} / \mathrm{s}], \dot{\varphi}_{3}\left(t_{1}\right)=$ $-4.1049[\mathrm{rad} / \mathrm{s}]$ の残留角速度が生じた .

\section{- STEP 2}

- (i) $(5<t<10)$ : 状態の保持 .

- (ii) $\left(10 \leq t \leq 25\left(=t_{2}\right)\right)$ : 円盤 3 の残留角速度 $\dot{\varphi}_{3}\left(t_{1}\right)$ を 0 に漸近させる .

命題 2 に従って軌道を計画し, 運動を 2 回繰り返 しおこなわせる . 2 回の運動ごとに $B$ は更新され る 、一度目の運動が終了したとき $(t=15[\mathrm{~s}])$ ，円 盤の角速度は $\dot{\varphi}_{1}(15)=4.1050[\mathrm{rad} / \mathrm{s}], \dot{\varphi}_{2}(15)=$ $-4.0228[\mathrm{rad} / \mathrm{s}], \dot{\varphi}_{3}(15)=-0.0822[\mathrm{rad} / \mathrm{s}]$ となっ た .二度目の運動か終了したとき，円盤の角速度は $\dot{\varphi}_{1}\left(t_{2}\right)=4.1050[\mathrm{rad} / \mathrm{s}], \dot{\varphi}_{2}\left(t_{2}\right)=-4.1033[\mathrm{rad} / \mathrm{s}]$, $\dot{\varphi}_{3}\left(t_{2}\right)=-0.0016[\mathrm{rad} / \mathrm{s}]$ となった .

- (iii) $(25<t<30)$ : 状態の保持 .

- (iv) $\left(30 \leq t \leq 45\left(=t_{3}\right)\right)$ : 円盤 2 の残留角速度 $\dot{\varphi}_{2}\left(t_{2}\right)$ を 0 に漸近させる .

同じく命題 2 に従って軌道を計画し, 運動を 2 回繰 り返しおこなわせる . 2 回の運動ごとに $B$ は更新さ れる.一度目の運動か終了したとき $(t=35[\mathrm{~s}])$ ，円 盤の角速度は $\dot{\varphi}_{1}(35)=0.0837[\mathrm{rad} / \mathrm{s}], \dot{\varphi}_{2}(35)=$ $-0.0821[\mathrm{rad} / \mathrm{s}], \dot{\varphi}_{3}(35)=-0.0016[\mathrm{rad} / \mathrm{s}]$ となっ た .二度目の運動が終了したとき，円盤の角速度は $\dot{\varphi}_{1}\left(t_{3}\right)=0.0034[\mathrm{rad} / \mathrm{s}], \dot{\varphi}_{2}\left(t_{3}\right)=-0.0016[\mathrm{rad} / \mathrm{s}]$, $\dot{\varphi}_{3}\left(t_{3}\right)=-0.0016[\mathrm{rad} / \mathrm{s}]$ となった .

シミュレーション結果はFigs.4-6である.各リンクの運動 軌道は目標軌道に重なっていて軌道追従が十分にできてい ることがわかる．運動を繰り返すことで，円盤の角速度は 0 に漸近させられることがわかる.最終的に各円盤の角速 度は $\dot{\varphi}_{1}(T)=0.0034[\mathrm{rad} / \mathrm{s}], \dot{\varphi}_{2}(T)=-0.0016[\mathrm{rad} / \mathrm{s}]$ ， $\dot{\varphi}_{3}(T)=-0.0016[\mathrm{rad} / \mathrm{s}]$ となった .

\section{5. おわりに}

2 次元平面内を運動する $N$ 自由度の TUM を対象にし てつぎの問題を考察した .

TUM の初期状態ではリンクが任意の位置で静止し各円 盤の角速度が 0 であるとき，TUMのリンクについては

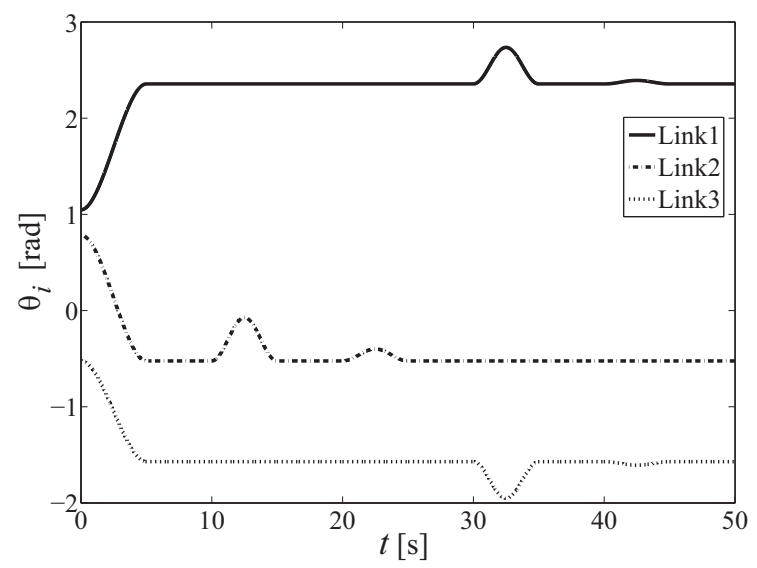

Fig. 4 Joint angles

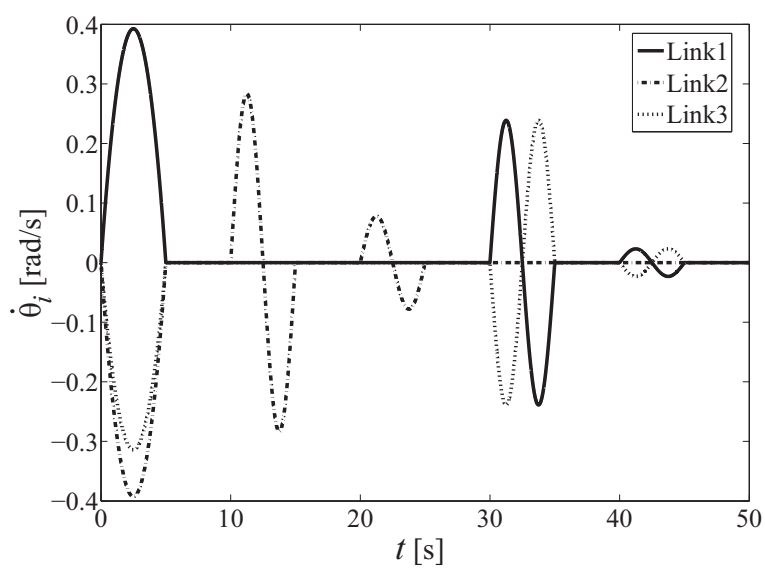

Fig. 5 Angular velocities of links

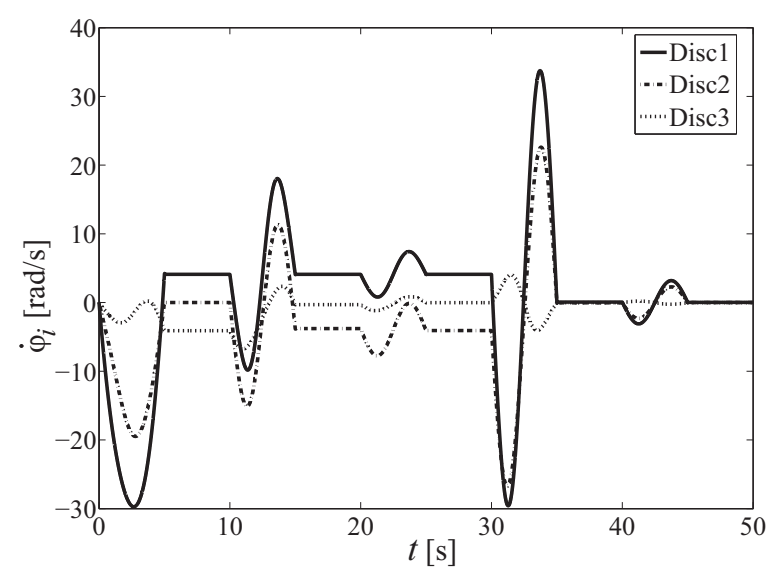

Fig. 6 Angular velocities of discs

任意の目標位置で静止させ , 各円盤の角速度を 0 にする ための制御方策を構成せよ。

この問題をつぎの二つに分けた .

・(1)リンクを目標位置に制御すること

- (2) 各円盤の角速度 0 にすること

TUM は円盤の運動を無視すれば通常のマニピュレータ 
と同樣に扱えるので, (1)に対しては通常のマニピュレー タに対してこれまでに提案された制御方法を用いること ができる . (2) に対しては円盤 $N$ の角速度を 0 に漸近さ せることから開始して順次円盤の角速度を 0 に漸近させ， 最終的にすべての円盤の角速度を 0 に漸近させるための リンクの運動軌道を計画する方法を与えた .この方法で の軌道計画は TUMのリンクや円盤の物理パラメータ值 に不確かさが含まれていても可能である.計画された運 動軌道への追従制御にはモデル誤差に対してロバストで 固定ゲイン型の制御則を用いる . 問題を二つに分けて解 決できることで，(1) と (2) を必ずしも連続しておこなう 必要はなく，TUMに(1)によって pick-and-place など の作業を連続しておこなわせた後に円盤の角速度の大き さを監視しながら，独立して (2) を実施するなどのこと も考えられる .

Arai ら [22-25] は平面内を運動するリンクに非駆動関 節によって力をおよぼす場合，リンクの長手方向と光れ に直交する方向とに分けることで光のリンクの衝撃中 心の位置と角度を独立に変更できるという物理的洞察 に基づいて一連の研究をおこなっている.この物理的事 実はDe Luca ら [13-18] によっても用いられ厳密な線形 化 [39] による $N$ 個の非駆動関節を持つマニピュレータ のフィードバック制御法が提案されている .このように 物理的な洞察は重要である. 本論文では円盤 $i$ の角速度 を目標の值に漸近させるためにはリンク $i-1$ と $i+1$ の 角速度を乥れ光れ正弦波状にしかもお互いが逆の方向 (マイナスが掛かる) になるような運動を繰り返すこと で達成できることを示した．しかし，このことの物理的 な解釈はなされていない．さきに述べた観点からこの系 をよりよく理解するために物理的解釈を今後の課題とす る.このことは, 目標を達成する運動軌道を得る際に物 理的なイメージや予想が先行したわけではないことを意 味する . 本論文における命題 2 で示した軌道については， (15) 式が (16) 式のように簡単になることが , 運動方程式 を詳細に調べることではじめて理解され，弚のように簡 単になるための運動軌道が満たすべき条件がわかり, 光 こから得られたものである .このような系を対象とする 場合に物理的な予想, あるいは物理的な解釈が難しいこ とが問題の解決における困難の一つであると思われる .

本論文の結果は，

・実験機による検証

か課題としてある．さらに，本論文では，重力の作用し ない 2 次元平面内のみを運動する TUM を対象にしてい たが,(重力がリンクに作用する場合，たとえばリンクを 静止状態にさせるためには，定常的なトルクをトルクユ ニットが発生する必要がある. 乥れは円盤の定常的な角 加速度運動を引き起こすため実際的ではない .)

- 宇宙空間のような重力の作用しない場合で 3 次元的 に運動する TUM に対して同樣の問題の考察

か課題となると思われる．また，すべての関節が非駆動
関節で構成された運動学鎖にトルクユニットを 2 個か 3 個で関節数より少ない個数を装着した劣駆動 TUMの構 成が考えられる．このような系の制御方策も今後の課題 である．また，Acrobot[17,40]やPendubot[41] は平面 内を運動する劣駆動系の一つであるが, これらを重力が 作用する鉛直面内で倒立させるための振上げ動作が研究 されている . 劣駆動 TUM では円盤の残留角速度を考慮 した同樣の問題は課題として挙げられる .

\section{参 考 文 献}

[1] K. Osuka, K. Yoshida and T. Ono: New design concept of space manipulator; Proc. of The 33rd IEEE Conference on Decision and Control, pp. 1823-1825 (1994)

[2] 大須賀, 吉田, 小野 : トルクュニットマニピュレータの 提案 ; 日本ロボット学会誌, Vol. 14, No. 7, pp. 104-111 (1996)

[3] M. L. Visinsky, J. R. Cavallaro and I. D. Walker : A dynamic fault tolerance framework for remote robots; IEEE Transactions on Robotics and Automation, Vol. 11, No. 4, pp. 477-489 (1995)

[4] S. Simant, C. Fantuzzi and R. Patton : Model-based Fault Diagnosis in Dynamic Systems using Identifeicatio Techniques, Springer-Verlag (2002)

[5] M. M. W. Dixon, D. Dawson and I. Walker : Fault detection and identification for robot manipulators; Proc. of 2004 IEEE International Conference on Robotics and Automation, pp. 4981-4986 (2004)

[6] A. De Luca and R. Mattone: An idetification scheme for robot actuator faults; Proc. of 2005 IEEE/RSJ International Conference on Intelligent Robots and Systems, pp. 634-639 (2005)

[7] A. De Luca and L. Ferrajoli : A modified NewtonEuler method for dynamic computations in robot fault detection and control; Proc. of 2009 IEEE International Conference on Robotics and Automation, pp. 3359-3364 (2009)

[8] 大須賀, 野原 : トルクユニットマニピュレータの軌道計 画による姿勢制御 - 非ホロノミック系としての取り扱 い- ; 日本ロボット学会誌, Vol. 18, No. 4, pp. 150-153 (2000)

[9] J. Imura, K. Kobayashi and T. Yoshikawa : Nonholonomic control of 3 link planar manipulator with a free joint; Proc. of IEEE Conference on Desicion and Control, pp. 1682-1687 (1996)

[10] K. Kobayashi and T. Yoshikawa : Controllability of under-actuated planar manipulators with one unactuated joint; Proc. of 2000 IEEE/RSJ International Conference on Intelligent Robots and System, pp. $133-138$ (2000)

[11] M. Reyhanoglu, A. van der Schaft and N. Harris : Nonlinear control of a class of under actuated systems; Proc. of 1996 IEEE International Conference on Robotics and Automation, pp. 2668-2675 (1996) 
[12] F. Bullo and K. M. Lynch : Kinematic controllability and decoupled trajectory planning for underactuated mechanical systems; Proc. of 2001 IEEE International Conference on Robotics and Automation, pp. 3300-3307 (2001)

[13] A. De Luca, R. Mattone and G. Oriolo : Control of underactuated mechanical systems: Application to the planar 2R robot; Proc. of IEEE Conference on Desicion and Control, pp. 1455-1460 (1996)

[14] A. De Luca, R. Mattone and G. Oriolo: Stabilization of an underactuated planar 2R manipulator; International Journal of Robust and Nonlinear Control, Vol. 10, pp. 181-198 (2000)

[15] A. De Luca and G. Oriolo : Motion planning and trajectory control of an underactuated three-link robot via dyanmic feedback linearization; Proc. of 2000 IEEE International Conference on Robotics and Automation, pp. 2789-2795 (2000)

[16] A. De Luca, S. I. R. Mattone and G. Oriolo : Underactuated manipulators: Control properties and techniques; Machine Intelligence and Robotic Control, Vol. 4, No. 3, pp. 113-126 (2002)

[17] A. De Luca and G. Oriolo : Trajectory planning and control for planar robots with passive last joint; The International Journal of Robotics Research, Vol. 21, No. 5-6, pp. 575-590 (2002)

[18] S. Iannitti and A. De Luca : Dynamic feedback control of XYnR planar robots with $\mathrm{n}$ rotational passive joints; Journal of Robotics Systems, Vol. 20, No. 5, pp. 251-270 (2003)

[19] G. Oriolo and Y. Nakamura:Free-joint manipulation: Motion control under second-order nonholonomic constraints; Proc. of IEEE/RSJ International Workshop on Intelligent Robots and Systems'91, pp. 12481253 (1991)

[20] 中村 , 濃沼 , 鈴木 : 自由関節を持つ平面アームのカ才 ス的挙動と非線形制御 - ドリフトを持つ非ホロノミッ ク機械の制御 - ; 日本ロボット学会誌, Vol. 14, No. 4, pp. 602-611 (1996)

[21] 鈴木，三好，中村 : 非ホロノミック自由関節マニピュ レータの制御 ; 日本ロボット学会誌, Vol. 19, No. 4, pp. 499-509 (2001)

[22] 荒井 : 非駆動関節を有する 3 自由度マニピュレータの非 ホロノミック拘束下における可制御性 ; 日本ロボット学 会誌, Vol. 14, No. 5, pp. 751-758 (1996)

[23] H. Arai, K. Tanie and N. Shiroma : Nonhoronomic control of a three-DOF planar underactuated manipulator; IEEE Transactions on Robotics and Automation, Vol. 14, No. 5, pp. 681-695 (1998)

[24] K. M. Lynch, N. Shiroma, H. Arai and K. Tanie: Collision-free trajectory planning for a 3-DoF robot with a passive joint; The International Journal of Robotics Research, Vol. 19, No. 12, pp. 1171-1184 (2000)

[25] N. Shiroma, H. Arai and K. Tanie : Nonhoronomic motion planning for coupled planar rogod bodirs with passive revolute joints; The International Journal of Robotics Research, Vol. 21, No. 5-6, pp. 563-574 (2002)

[26] S. K. Agrawal and V. Sangwan : Differentially flat designs of underactuated open-chain planar robots; IEEE Transactions on Robotics, Vol. 24, No. 6, pp. 1445-1451 (2008)

[27] B. Roy and H. H. Asada : Nonlinear feedback control of a gravity-assisted underactuated manipulator with application to aircraft assembly; IEEE Transactions on Robotics, Vol. 25, No. 5, pp. 1125-1133 (2009)

[28] 吉田 , 大須賀 : トルクユニットマニピュレータの全状態 変数を制御するための運動軌道に関する考察 ; 日本口 ボット学会誌, Vol. 25, No. 7, pp. 1108-1117 (2007)

[29] たとえば, J. E. Marsden and T. S. Ratiu:Introduction to Mechanics and Symmetry, 2nd edition, SpringerVerlag (1999)

[30] Z. Li, R. Montgomery and M. Raibert : Dynamics and optimal control of a legged robot in flight phase; Proc. of IEEE International Conference on Robotics and Automation, pp. 1816-1821 (1989)

[31] R. E. Murray and S. S. Sastry: Nonholonomic motion planning: Steering using sinusoids; IEEE Trans. on Automat. Contr., Vol. 38, No. 5, pp. 700-716 (1993)

[32] G. C. Walsh and S. S. Sastry : On reorienting linked rigid bodies using internal motions; IEEE Transactions on Robotics and Automation, Vol. 11, No. 1, pp. 139-146 (1995)

[33] J. Ostrowski and J. Burdick : Gait kinematics for a serpentine robot; Proc. of 1996 IEEE International Conference on Robotics and Automation, pp. 12941299 (1996)

[34] 石川 : 三叉へビ型ロボットの推進原理と周期入力による 制御; 計測自動制御学会論文集, Vol. 39, No. 5, pp. 520528 (2006)

[35] F. Pfeiffer and R. Johanni : A concept for manipulator trajectory planning; IEEE Journal of Robotics Automat., Vol. RA-3, No. 2, pp. 115-123 (1987)

[36] J.-J. E. Slotine and H. S. Yang : Improving the efficiency of time-optimal path-following algorithms; IEEE Transactions on Robotics and Automation, Vol. 5, No. 1, pp. 118-124 (1989)

[37] Z. Shiller and S. Dubowsky: On computing the grobal time-optimal motions of robotic manipulators in the presence of obstacles; IEEE Transactions on Robotics and Automation, Vol. 7, No. 6, pp. 785-797 (1991)

[38] 大須賀, 杉江, 小野 : マニピュレータの PD 型二重構 造ロバストモデル追従制御; 計測自動制御学会論文集, Vol. 25, No. 1, pp. 46-53 (1989)

[39] A. Isidori : Nonlinear Control Systems, 3rd edition, Springer-Verlag (1995)

[40] M. W. Spong: The swing up control problem for the acrobot; IEEE Control Systems, Vol. 15, No. 1, pp. 49-55 (1995) 
[41] M. W. Spong and D. Block: The Pendubot:A mechatronic system for control research and education; Proc. of the 34th IEEE Conference on Decision and Control, pp. 555-557 (1995)

\section{著 者略歴}

\section{呰蓄浩治 (正会員)}

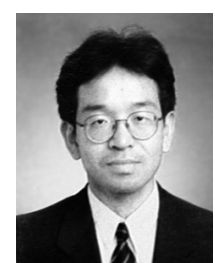

1993 年大阪大学大学院基礎工学研究科 博士後期課程単位取得認定退学.同年, 大 阪府立大学工学部助手. 1997 年岡山県立 大学情報工学部講師，助教授を経て，2006 年岡山理科大学工学部助教授, 2008 年同 教授, 現在に至る.制御工学やロボティク スなどの研究に従事. 博士 (工学) . 日本ロボット学会, 計 測自動制御学会, 日本機械学会, IEEEなどの会員.

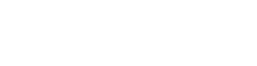

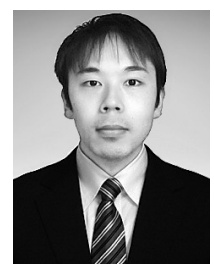

2011 年岡山理科大学工学部機械システ 厶工学科卒業. 現在, 岡山理科大学大学院 工学研究科修士課程在学中. 制御工学に関 する研究に従事 .
笠等盖也 (正会員)

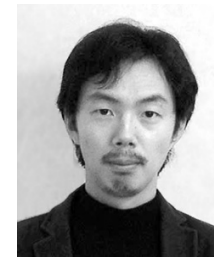

1999 年大阪府立大学大学院工学研究科 博士後期課程修了 . 同年津山工業高等専門 学校助手, 2002 年岡山理科大学工学部機 械システム工学科講師を経て，2008 年同 准教授，現在に至る．2006 年〜2007 年， Institute de Recherche en Communications et Cybernétique de Nantes 客員研究員. 制御工学, ロ ボティクスに関する研究に従事. 博士 (工学) . 日本ロボット 学会, 計測自動制御学会, 日本機械学会, IEEEなどの会員.

\section{福望策吾}

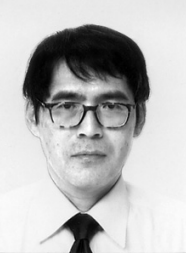

1983 年大阪府立大学工学部機械工学科 卒業.大和製衡 (株) を経て, 1995 年応用 計測工業 (株) 入社. 炎の後, 2003 年に姫 路工業大学大学院工学研究科博士後期課程 修了.はかりの設計, 研究開発, 振動デー 夕の現場計測，解析などに従事した.2011 年株式会社創発システム研究所に入社, 現在は動的質量計測 や制御工学に関する研究に従事. 博士 (工学) . 計測自動制 御学会などの会員 .

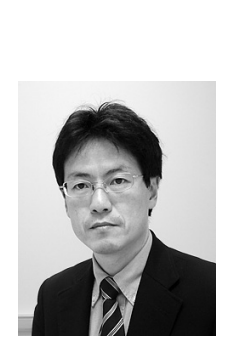

(正会員)

1984 年大阪大学大学院基礎工学研究科 修士課程修了. 同年 (株) 東芝入社, 総合 研究所勤務. 1986 年大阪府立大学工学部 助手．弚の後，同講師，同助教授を経て， 1998 年京都大学大学院情報学研究科助教 授，2003 年神戶大学工学部教授, 2009 年 大阪大学大学院工学研究科教授, 現在に至る.ロボティクス, 制御工学の研究に従事. 博士 (工学). 日本ロボット学会, 計 測自動制御学会, 日本機械学会, IEEEなどの会員. 